\title{
Impact and economic value of agricultural land conversion in sub-urban of Bantul Regency
}

\author{
Hestina Fandani*, and Rika Harini \\ Department of Environmental Geography, Faculty of Geography, Universitas Gadjah Mada, Bulaksumur, Yogyakarta 55281, \\ Indonesia
}

\begin{abstract}
Increasing the number of populations in urban areas results in increasing the need for shelter and food, while the land area is limited. This has led to a conversion of agricultural land to non-agricultural land, especially in sub-urban areas that directly adjacent to urban areas. This study aimed to identify the impact of agricultural land conversion, and also to estimate the economic value of paddy land loss in sub-urban of Bantul Regency. Data were collected through structured interviews, institutional data, and literature reviews. These data were analyzed in a quantitative descriptive. Most of the paddy fields are converted for home and housing, partially used for economic activities that have higher land rent such as shops, boarding houses, and restaurants. The perceived impact is increasing air temperature, air pollution, also reduced employment opportunities and income from agricultural sector. The total economic value of the direct use obtained from the existence of agricultural land in Bantul sub-urban is IDR $96806832 \mathrm{ha}^{-1} \mathrm{yr}^{-1}$. It is includes the value of rice production of IDR $53934540 \mathrm{ha}^{-1} \mathrm{yr}^{-1}$, the value of employment opportunities is IDR 17126688 $\mathrm{ha}^{-1} \mathrm{yr}^{-1}$ and the value of agricultural income is IDR $25745604 \mathrm{ha}^{-1} \mathrm{yr}^{-1}$
\end{abstract}

\section{Introduction}

The increase in population results in increasing demand for shelter and food, while the land area is limited. This causes competition in land use for agriculture and nonagriculture, and then occurred the agricultural land conversion [1]. Land use conversion has largely and is occurring in developing countries [2]. Paddy fields have the characteristics of land that is generally flat, close to water sources, and easy to accessed, so that paddy land is a target of land converted to development activities [3]. Urban areas are the most massive areas that have land conversion cases [4]. Additionally, sub-urban are also areas that have high potential for agricultural land conversion. This happens because this area is the main destination for the residence of commuter workers in the city [5]. In addition, because of the location is affordability, the price of land in this area is also relatively cheaper than in the center of city.

Bantul Regency is one of the administrative regions directly adjacent to the Yogyakarta City, so its economic conditions are affected by the urban economy due to urban sprawl phenomenon. Sub-urban of Bantul Regency includes 3 sub-district, namely Banguntapan, Sewon, and Kasihan Sub-district (Figure 1). Demands for the city development effected to rapidly development in suburban areas. This happens because uban economic growth requires wider land for the construction of various infrastructure and public facilities as centers of human activity, such as settlements , educational facilities, industrial activities, etc.

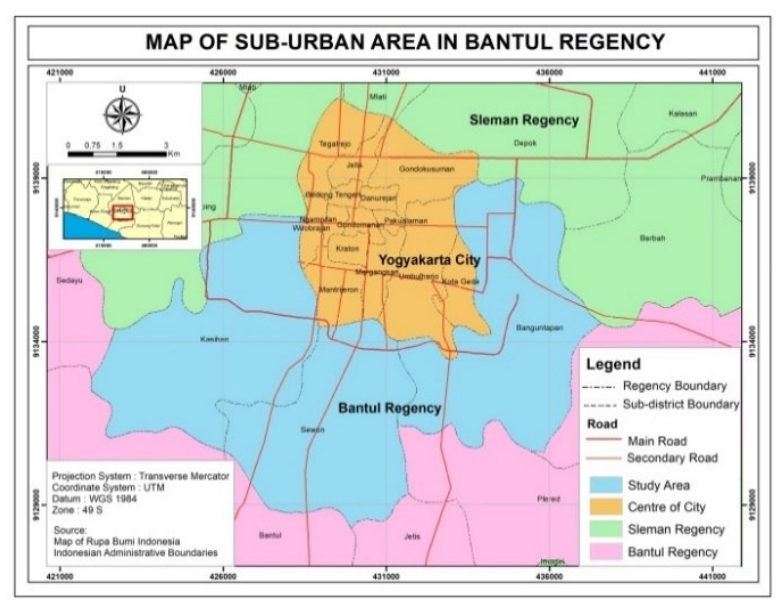

Fig. 1. Map of sub-urban areas in Bantul Regency

Land conversion activities will have the impact, especially in economic aspects, because in Indonesia, the agricultural sector is the main sector that is most influential on an economic basis [6]. Economic valuation for agricultural land conversion is important to calculated, these to determine the economic value of the lost [7]. The study of the impact of agricultural land conversion, and the calculation of the economic value of agricultural land is needed as an effort to control the existence of land conversion. This study aims to identify the impact of agricultural land conversion and then estimate the economic value of agricultural land is lost due to land conversion in Bantul sub-urban area.

\footnotetext{
* Corresponding author: hestina.fandani@mail.ugm.ac.id
} 


\section{Methods}

\subsection{Study area}

The location of the study was conducted in 3 sub-districts in Bantul Regency which are directly adjacent to the Yogyakarta City, namely Banguntapan Sub-district, Sewon Sub-district, and Kasihan Sub-district. In each sub-district, one village was chosen as the focus of the research location using a purposive technique. Locations were selected on village with the largest paddy fields conversion area, during the period 2011-2017. It results that Bangunharjo, Wirokerten, and Ngestiharjo are villages with the largest paddy fields conversion at each sub-district.

The location of the study was focused on 5 subvillages chosen randomly as a sample of the area from each of the selected villages. The selection of sub-village is carried out randomly because all sub-villages in each village are considered to have the same characteristics and have the same opportunity to be sampled as a region. The sub-villages used as sample regions in the study are as follows (Table 1).

Table 1. Research Locations

\begin{tabular}{|l|l|l|l|l|l|}
\hline \multicolumn{2}{|c|}{ Wirokerten } & \multicolumn{2}{c|}{ Bangunharjo } & \multicolumn{2}{c|}{ Ngestiharjo } \\
\hline No & $\begin{array}{c}\text { Sub-village } \\
\text { Name }\end{array}$ & No & $\begin{array}{c}\text { Sub- } \\
\text { village } \\
\text { Name }\end{array}$ & No & $\begin{array}{c}\text { Sub- } \\
\text { village } \\
\text { Name }\end{array}$ \\
\hline 1 & Grojogan & 1 & Wojo & 1 & Tambak \\
\hline 2 & Sampangan & 2 & Saman & 2 & Cungkuk \\
\hline 3 & Glondong & 3 & Tarudan & 3 & Kadipiro \\
\hline 4 & $\begin{array}{l}\text { Kepuh } \\
\text { Wetan }\end{array}$ & 4 & Ngoto & 4 & $\begin{array}{l}\text { Sonopakis } \\
\text { Lor }\end{array}$ \\
\hline 5 & Mutihan & 5 & Bakung & 5 & $\begin{array}{l}\text { Sonopakis } \\
\text { Kidul }\end{array}$ \\
\hline
\end{tabular}

\subsection{Data collection and analysis}

Data used in the study were obtained through structured interviews and the data from publications of institutions. The population in this study were paddy land owners who had converted their land to non-agriculture during 20102019 in 5 sub-villages in each of Bangunharjo Village, Wirokerten Village, and Ngestiharjo Village. 45 respondents were obtained using the census method.

Data analysis uses quantitative descriptive methods. Assessment of the impact using the likert scale is given a score. The provision of scores starting from the range 1 to 5 , i.e $1=$ very disagree, $2=$ disagree, $3=$ doubtful, $4=$ agree, $5=$ very agree. The total results of the total score is divided into 3 classes of impact, namely low, medium, and high. In this analysis, the possibilities of the lowest points that can be collected is 45 points, and the highest point is 225 points. Based on the score obtained the class division is low (45 to 104 points), medium (105 to 164 points), and high (165 to 225 points).

The economic value is calculated by mathematical equations. Economic values calculated include the economic value of rice commodity production, the value of employment opportunity, and the value of agricultural income. Calculation of economic value to calculate the value of lost production using Equation 1 [8].

$$
\mathrm{CPV}=\sum(\mathrm{Ai} \times \mathrm{Pi} \times \mathrm{Pri})
$$

Where CPV is the value of commodity production (IDR/ha/year), Ai is the land area of commodity $\mathrm{i}$ (ha), $\mathrm{Pi}$ is the productivity of commodity $\mathrm{i}(\mathrm{kg} / \mathrm{ha} / \mathrm{year})$, Pri is the price of commodity i (IDR/kg).

The economic value equation for employment opportunities is shown in Equation 2 [8].

$$
\mathrm{EOV}=\sum(\mathrm{Ai} \times \mathrm{Ni} \times \mathrm{Wi})
$$

Where EOV is the value of employment opportunities in paddy fields (IDR/ha/year), Ni is the need for farm labor (Working Day People/ha/year), Wi is the work wages (IDR/Working Day People).

The value of agricultural income can be described through Equation 3[9]:

$$
\pi=T R-T C
$$

Where $\pi$ is the income of agricultural sector, TR is the total revenue (IDR/ha/year), TC is the total costs (IDR/ha/year.

\section{Results and discussion}

\subsection{Social and economic characteristics}

The subject of land conversion are dominated by people with productive age groups $(76 \%)$. The age group that mostly converted their agricultural land is $55 \mathrm{yr}$ old to 64 yr old. At this age, usually the physical ability to work decreases. The majority of household members consists of 3 to 4 people, so it is included in small households according to BKKBN (Agency of National Demography in Indonesia). The level of education in the research location has high variation, low levels of education (not schooling and elementary school) and higher education (senior high school and diploma/bachelor) are equally dominant. This phenomenon indicates that there is still an inequality in obtaining education that occurred in the community.

The land conversion activities is mostly carried out by people who work in the non-agricultural sector $(87 \%)$. People who converted their land have a low to moderate main income category and narrow paddy land. The average income is IDR 1958889 with land owned $<1000$ $\mathrm{m}^{2}$. One of the motivations for land conversion is low production yields. The area of paddy fields has a positive effect on farming production and agricultural income [10]. That is, the smaller area of paddy fields, the farming production and agricultural income is also getting smaller, so there is a tendency to convert the agricultural land to other uses that more economically profitable. 


\subsection{Impact of agricultural land conversion}

\subsubsection{Land use change}

Land conversions that occurred in research locations are permanent land use change. Paddy fields are often converted to non-agricultural land uses, such as houses, shops, housing, and various public facilities such as campuses, mosques and pharmacies. Most of the paddy fields were converted to houses and housing (Figure s2). The community tends to convert their paddy fields to build houses because of the limited land they have. Built up a house in a paddy field is the best choice according to them when compared to having to buy land in another location whose price might be more expensive.

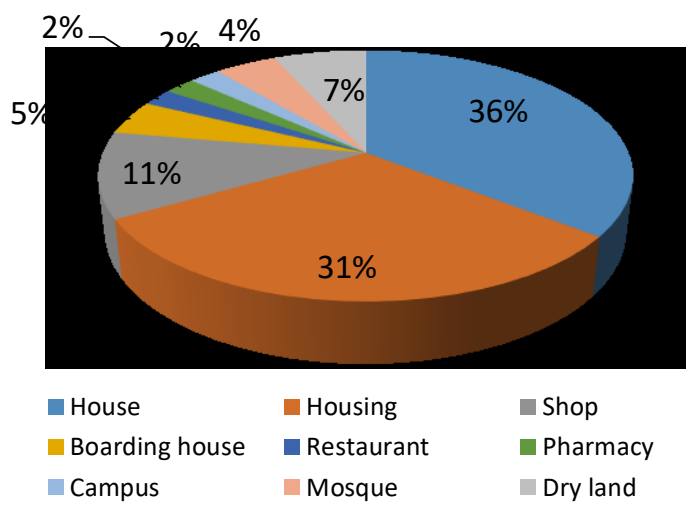

Fig. 2. Types of land use after the conversion.

The increasing need for residential land in sub-urban areas is seen as an attractive economic opportunity for developers to build housing. Therefore, many developers looking for paddy fields to be bought and converted to housing. Some paddy fields are converted to shops, boarding houses, restaurants, and pharmacies because they are more profitable than land used for farming activities. This reveals that the agricultural land is allocated to other forms of use with a higher land rent value to obtain an economic surplus.

\subsubsection{Perception of environmental and economical impact}

Massive development activities in sub urban areas due to the conversion of agricultural land has an impact on environmental and economic conditions. Based on environmental aspects, paddy fields have functions as flood control, biodiversity conservation, absorbent organic waste and air conditioning [11]. In this analysis, the impact assessment is focused on the problem of the function of paddy fields as air conditioning and flood control only. This is because air pollution and flooding are environmental problems that are most often found in urban and surrounding areas.

The impact of agricultural land conversion on air condition is measured through two aspects, i.e. the perception of air freshness and air temperature. Agricultural land conversion has a high impact for the air freshness and temperature. People feel the impact in the form of air that is not fresh and the temperature is getting hotter due to the conversion of agricultural land. This can be seen from the high percentage of community perceptions, the majority of which agree (Table 2). The conversion of agricultural land to non-agriculture causes the reduction of green open land. Without vegetation, the air temperature is relatively hotter when compared to places that are still much overgrown with vegetation.

In the tropics, besides being used for rice cultivation, paddy fields are also known as an effective area for collecting runoff water during the rainy season [12]. The land is built with concrete and asphalt resulting in reduced land for water catchment. When there is a high intensity of rainfall, there will be a lot of puddles because the water is not absorbed well into the soil. This potentially for flooding occurs.

Table 2 shows that the agricultural land conversion has a low level impact for floods risk. In the research location, it is rarely found a flood, both before and after land conversion. This occurred because the drainage is still functioning properly. As explained in the previously study, that drainage conditions are variables that most influence on susceptibility to flooding [13]. If the drainage conditions are bad, it is prone to flooding, and vice versa if the drainage conditions are good there will be no flooding.

From an economic perspective, agricultural land conversion has high impact level on reduced employment opportunities in the agricultural sector (Table 2). This shows the same results with a research in Ingham, Eaton, and Clinton [14]. Agricultural land conversion results in a loss of opportunity to obtain income from paddy farming due to land that has been sold or converted to other uses. The people most affected in this case are those who work as farmers or farm laborers.

Land conversion also has high impact level for the decrease in agricultural income. Most of the land owner in the research location sell or convert more than half of the total area of paddy fields owned. The farming production will be lost as much as the area of paddy fields is converted. Based on table 2, it is known that the majority of respondents agree that agricultural land conversion cause a reduction in agricultural income. This shows the same results with the previously study, that the farming production have positive correlation to agricultural income, so that when production decreases the income derived from farming activity also decreases [15].

\subsection{The economic value of agricultural land conversion}

The economic value of agricultural land is calculated through estimation of the multifunctional economic value of paddy fields. In this study, the assessment only focuses on economic valuation according to the benefits of paddy fields direct using which include the value of rice production, employment opportunities, and agricultural income [16]. The economic value is calculated using the market price approach. Pricing is based on market prices when the research takes place. 
Table 2. Environmental and economical impact of agricultural land conversion

\begin{tabular}{|c|c|c|c|c|c|c|c|}
\hline \multirow[b]{2}{*}{ Impact } & \multicolumn{5}{|c|}{ Number } & \multirow[b]{2}{*}{ Score } & \multirow{2}{*}{$\begin{array}{c}\text { Level of } \\
\text { Impact }\end{array}$} \\
\hline & $\begin{array}{l}\text { Strongly } \\
\text { agree }\end{array}$ & Agree & Doubtful & Disagree & $\begin{array}{l}\text { Strongly } \\
\text { Disagree }\end{array}$ & & \\
\hline Decreased air freshness & 3 & 30 & 7 & 5 & 0 & 166 & High \\
\hline Increased air temperature & 8 & 26 & 7 & 4 & 0 & 173 & High \\
\hline Increased flood potential & 0 & 3 & 3 & 36 & 3 & 96 & Low \\
\hline $\begin{array}{l}\text { Decrease in agricultural employment } \\
\text { opportunities }\end{array}$ & 21 & 18 & 1 & 5 & 0 & 190 & High \\
\hline Decrease in agricultural income & 18 & 25 & 2 & 0 & 0 & 196 & High \\
\hline
\end{tabular}

\subsubsection{Value of rice production}

Bantul Regency has the second largest of agricultural land in the province (Figure 3). The larger agricultural land will support more production levels. Economic losses are higher as the productivity of converted paddy fields [12]. The average productivity in Bantul suburban is $3740 \mathrm{~kg} \mathrm{ha}^{-1}$ in one harvest period. Within a year, on average there are 3 times the harvest period. If the paddy field is converted to non-agricultural land, the paddy field potentially will lose $11220 \mathrm{~kg} \mathrm{ha}^{-1} \mathrm{yr}^{-1}$ of paddy production. The average price of rice in the study area was IDR $4807 \mathrm{~kg}^{-1}$. By using the formula of the equation 1 then result that the economic value of lost rice production in sub-urban areas of Bantul amounting to IDR $53934540 \mathrm{ha}^{-1} \mathrm{yr}^{-1}$.

\section{Land Area ( $\mathrm{Ha})$}
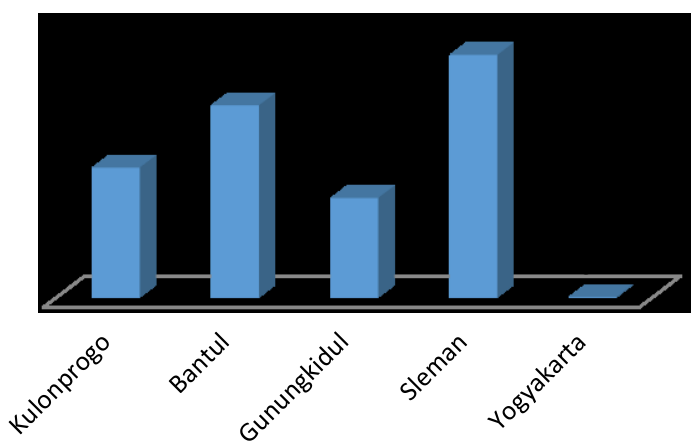

Fig. 3. Paddy Area by Regency in DIY 2017

\subsubsection{Value of employment opportunity}

The value of employment opportunities discussed in this study is limited to the use of External Family
Workers that are directly related to paddy farming, such as labor for cultivating land, nurseries, planting, fertilizing, spraying pesticides, weeding, and harvesting. The use of labor in the study site consisted of male and female laborers, which is stated by Working Day People (WDP). The amount of wages provided between male and female workers is the same, not genderdifferentiated.

The cost component for agricultural labor in table 3, shows that planting labor is the highest labor cost of IDR. $1569206 \mathrm{ha}^{-1}$ and the lowest cost is a nursery that is IDR $200000 \mathrm{ha}^{-1}$ in every one planting period. The high cost of planting is due to the majority of planting workers are workers outside the family and also requires a lot of labor that is 22.4 Working Day People. Whereas nursery costs are the lowest cost because most of them use internal family labor and the need for labor is small, which is only 2 working day people.

The average labor requirement in a planting period on one hectare of paddy fields are 68.3 working day people with labor costs amounting to IDR 5708 896. In a year, there are 3 times the planting period, so that the total labor cost incurred is IDR $17126688 \mathrm{ha}^{-1}$ $\mathrm{yr}^{-1}$. Land conversion cause changes in aspects of employment opportunities. Based on the results of these calculations, then in every one hectare of converted paddy land can potentially eliminate employment opportunities in the agricultural sector as many as 204.9 working day people with an economic value of IDR $17126688 \mathrm{ha}^{-1} \mathrm{yr}^{-1}$. 
Table 3. The components value of employment opportunities/planting period

\begin{tabular}{|l|r|r|r|}
\hline \multicolumn{1}{|c|}{ Labor } & \multicolumn{1}{c|}{ WDP } & \multicolumn{1}{c|}{$\begin{array}{l}\text { Wages } \\
\text { (IDR) }\end{array}$} & \multicolumn{1}{c|}{$\begin{array}{l}\text { Value } \\
\text { (IDR) }\end{array}$} \\
\hline Land management & 5.6 & 250000 & 1394740 \\
\hline Nursery & 2.0 & 100000 & 200000 \\
\hline Planting & 22.4 & 70000 & 1569206 \\
\hline Fertilizing & 5.4 & 50000 & 268000 \\
\hline Spraying & 8.6 & 50000 & 430700 \\
\hline Weeding & 10.0 & 70000 & 700000 \\
\hline Harvesting & 14.3 & 80000 & 1146250 \\
\hline \multicolumn{3}{|c|}{} & 5708896 \\
\hline
\end{tabular}

\subsubsection{Value of agricultural income}

Agricultural income is the amount of money that can be obtained from farming in paddy fields. The level of production will determine the amount of agricultural income that will be received. The higher rate of production, the higher the agricultural income. The calculation results show that the average farm income received is IDR $53934540 \mathrm{ha}^{-1} \mathrm{yr}^{-1}$.

Costs in farming include fixed costs and variable costs. Variable costs are costs incurred routinely with a relatively fixed nominal. The amount of fixed costs is not affected by production, whereas for variable costs, the amount of costs is influenced by production [17]. The average total cost incurred in farming is IDR $28188936 \mathrm{ha}^{-1} \mathrm{yr}^{-1}$. The highest cost component is the cost of labor, IDR $17126688 \mathrm{ha}^{-1} \mathrm{yr}^{-1}$ (Table 4). The agricultural sector is requiring a lot of labor in farming, thus requiring high costs for labor wages.

Table 4. The component value of total farming revenue and costs

\begin{tabular}{|l|r|}
\hline \multicolumn{1}{|c|}{ Information } & Value (IDR/ha/year) \\
\hline Farming revenue & 53934540 \\
\hline Fixed cost & \\
a. Tax of land & 3671313 \\
Variable cost & \\
a. Seed & 778875 \\
b. Fertilizer & 5016060 \\
c. Pesticide & 1596000 \\
d. Labor & 17126688 \\
Total Cost & 28188936 \\
\hline Income & 25745604 \\
\hline
\end{tabular}

Land conversion of paddy fields causes loss of agricultural income that should be received by the land owner. Agricultural income is obtained by calculating the difference between total revenue with the total costs. The results of indicate that agricultural income obtained an average of IDR $25745604 \mathrm{ha}^{-1} \mathrm{yr}^{-1}$. It means that in every one hectare of converted paddy land, it will potentially eliminate agricultural income of IDR 25745604 .

\subsubsection{Total benefit economic value of agricultural land direct usage}

The total value of agricultural land direct usage in Bantul sub urban area is IDR $96806832 \mathrm{ha}^{-1} \mathrm{yr}^{-1}$. The value can represent the amount of the benefits obtained directly by land owners and agricultural workers. The highest value composition is the value of agricultural land production, i.e. IDR $53934540 \mathrm{ha}^{-1} \mathrm{yr}^{-1}$ (Figure 4). This indicates that the conversion of agricultural land greatly affect the loss of rice production.

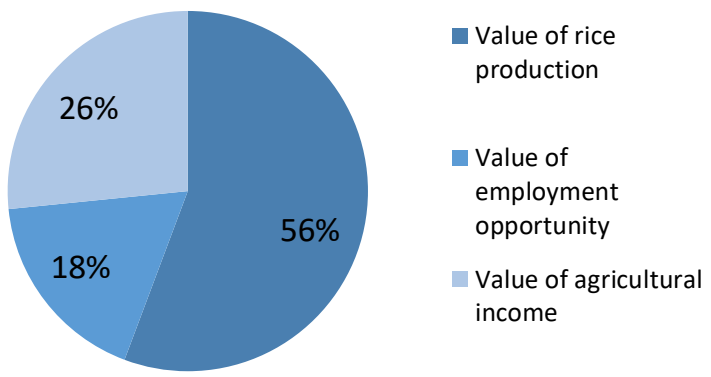

Fig. 4. Contribution of total economic value benefits of direct usage of agricultural land

\section{Conclusions}

Communities tend to convert their farmland for more profitable use. Most of the paddy fields are converted for houses and housing, partially used for economic activities such as shops, boarding houses, and restaurants. The high-level impact that is felt by communities are the decreased of air freshness quality, increased air temperature, the loss of employment, and decreased agricultural income. Whereas the impact on flood vulnerability is a low-level impact.

The total economic value of the direct use obtained from the existence of agricultural land in Bantul suburban is IDR $96806832 \mathrm{ha}^{-1} \mathrm{yr}^{-1}$. The value consists of rice production value of IDR $53934540 \mathrm{ha}^{-1} \mathrm{yr}^{-1}$, the value of employment is IDR $17126688 \mathrm{ha}^{-1} \mathrm{yr}^{-1}$ and the value of agricultural income is IDR 25745604 $\mathrm{ha}^{-1} \mathrm{yr}^{-1}$. Rice production value is the highest economic value, meaning that the function of agricultural land has greatly impact the loss of rice production.

The authors would like to thank the Directorate of Research of Universitas Gadjah Mada for financial support the research through "Rekognisi Tugas Akhir (RTA) 2020".

\section{References}

1. Hossaimah, S. Subari, Agrisaintifika. J. 1, 2: 97108 (2017)

2. B. Lanz, S. Dietz, T. Swanson, Amer. J. Agr. Econ, 100, 2: 545-569 (2018)

3. A. Mulyani, D. Kuncoro, D. Nursyamsi, F. Agus, J. Tanah dan Iklim, 40, 2: 121-133 (2016)

4. N. Rusono, A. Sunan, Zulfriandi, J. Indarto, A. Muharam, N. Avianto, D. Hersinta, Evaluasi 
Implementasi Kebijakan Lahan Pertanian Pangan Berkelanjutan (LP2B), in Direktorat Pangan dan Pertanian, Bappenas (2015)

5. J.T. Hidajat, S.R. Sitorus, E. Rustiadi, Machfud, J. Globe, 15, 1: 93-100 (2013)

6. FAO, The Role of Agriculture in the Development of Least-developed Countries and their Integration into the World Economy, in Fao. Commodities and Trade Division, FAO (2002)

7. S. Sudirman, J. Agrika, 6, 1: 103-125 (2012)

8. Irawan, B. Sanim, H. Siregar, U. Kurnia, J. Ilmu Pertanian Indonesia, 11, 3: 32-41 (2006)

9. Y. Hidayat, A. Ismail, M. Ekayani, J. Pengkajian dan Pengembangan Teknologi Pertanian, 20, 2: 171-182 (2017)

10. A.A. Andrias, Y. Darusman, M. Ramdan, J. Ilmiah Mahasiswa Agroinfo Galuh, 4, 1: 521-529 (2017)

11. Mukhoriyah, Kajian Nilai Ekologi-Ekonomi Lahan Sawah dan Kaitannya dengan Rencana Tata Ruang di Kota Depok, M.S. Thesis, Indonesia University, Depok (2012)

12. Sumaryanto, S. Friyatno, B. Irawan, Konversi Lahan Sawah ke Penggunaan Non Pertanian dan Dampak Negatifnya, in Proceeding of Seminar Nasional Multifungsi Lahan Sawah, Bogor (2005)

13. A.R. Rachmat, A. Pamungkas, J. Teknik Pomits, 3, 2: 3-8 (2014)

14. G. Schultink, J. of Civil, Environmental, and Architectural Engineering, 3, 1 (2009)

15. D.A. Pasaribu, Pengaruh Alih Fungsi Lahan Pertanian Terhadap Kondisi Ekonomi Rumah Tangga, B.S. Thesis, Bogor Agricultural Institute, Bogor (2019)

16. H.N. Handayani, R. Harini, J. Bumi Indonesia, 6, 4 (2017)

17. P.A. Suardana, M. Antara, M.N. Alam, J. Agrotekbis, 1, 5: 477-484 (2013) 